\title{
00R_TASIOH
}

Available online at Website http://ejournal.undip.ac.id/index.php/rotasi

\section{DETEKSI KERUSAKAN RODA GIGI DENGAN ANALISIS SINYAL GETARAN}

\author{
*Achmad Widodo, Djoeli Satrijo, Toni Prahasto \\ Jurusan Teknik Mesin, Fakultas Teknik, Universitas Diponegoro \\ J1. Prof. Sudharto, SH., Tembalang-Semarang 50275, Telp. +62247460059 \\ *Email: awid@undip.ac.id
}

\begin{abstract}
ABSTRAK
Roda gigi adalah salah satu komponen mesin yang banyak digunakan dalam sistem transmisi daya. Roda gigi meneruskan daya dari motor melalui mekanisme kontak antar gigi-gigi pada gear dengan gigi-gigi pada pinion. Dengan mekanisme ini, diharapkan tidak terjadi slip selama proses transmisi daya berlangsung. Akibat adanya beban kontak dan kondisi operasi, kerusakan roda gigi dapat terjadi baik kerusakan permukaan seperti pitting, scoring maupun gigi patah. Kerusakan tersebut berpengaruh terhadap kinerja roda gigi, timbulnya noise dan getaran yang berlebih. Oleh karena itu, deteksi dini dari kerusakan roda gigi diperlukan karena dapat mengurangi kerugian terjadinya kerusakan yang bersifat katastropik. Penelitian ini bertujuan untuk menganalisis karakteristik sinyal getaran domain waktu dan frekuensi roda gigi pada kondisi normal, aus dan patah. Metode penelitian ini dilakukan dengan menggunakan test rig roda gigi lurus dengan rasio 1:2. Data akuisisi sinyal getaran dilakukan pada putaran $1000 \mathrm{rpm}$. Analisis sinyal getaran dilakukan dengan time synchronous averaging (TSA), wavelet transform dan cepstrum. Hasil analisis menunjukkan bahwa metode TSA dan wavelet mampu mendeteksi kerusakan roda gigi serta mampu menentukan lokasi relatif dari cacat roda gigi berdasarkan sudut putar. Metode cepstrum mampu mendetekasi frekuensi kerusakan roda gigi tetapi tidak bisa menentukan lokasi relatif cacat roda gigi berdasar sudut putar.
\end{abstract}

Kata kunci: getaran, diagnosa kerusakan, roda gigi, cepstrum, wavelet, time synchronous averaging.

\section{Pendahuluan}

Roda gigi adalah salah satu komponen mesin yang banyak digunakan dalam sistem transmisi daya. Roda gigi juga merupakan komponen pengubah tingkat putaran poros pada mesin yang dapat mengurangi dan menaikan kecepatan tergantung pada pengaturan gigi. Roda gigi meneruskan daya dari motor melalui mekanisme kontak antar gigi-gigi pada gear dengan gigi-gigi pada pinion. Dengan mekanisme ini, diharapkan tidak terjadi slip selama proses transmisi daya berlangsung.

Sistem transmisi daya menggunakan roda gigi telah banyak digunakan pada berbagai jenis penggerak. Kelebihan dari sistem transmisi roda gigi adalah sebagai berikut:

1) Sistem transmisinya lebih ringkas dan kapasitas daya yang dapat diteruskan relatif besar.

2) Sistem yang kompak sehingga konstruksinya sederhana dan butuh ruang yang kecil.

3) Faktor terjadinya slip sangat kecil sehingga efisiensi pemindahan dayanya tinggi.

4) Keandalannya cukup tinggi, artinya umur pakai cukup lama.

5) Perawatannya mudah.

Walaupun demikian, kerusakan atau cacat roda gigi tetap dapat terjadi pada roda gigi yang telah dipakai dalam jangka waktu tertentu. Setiap kerusakan kecil pada roda gigi tersebut menyebabkan kegagalan yang tak terduga pada mesin dan akan menyebabkan kerugian yang signifikan dalam hal waktu dan uang. Deteksi dini dari kerusakan roda gigi dapat mengurangi kerugian tersebut. Salah satu cara mendeteksi dini kerusakan adalah dengan menganalisa sinyal getaran yang dihasilkan dari roda gigi [1].

Penelitian ini dilakukan dengan tujuan untuk mendeteksi kerusakan roda gigi dengan menggunakan sinyal getaran. Metode dalam analisis sinyal dilakukan dengan time synchronous averaging, wavelet transform dan cepstrum.

\section{Bahan dan Metode Penelitian}

Data akuisisi sinyal getaran dilakukan pada test-rig roda gigi lurus dengan putaran $1000 \mathrm{rpm}$. Sinyal getaran yang diterima oleh sensor accelerometer selanjutnya akan diolah dengan software VibraQuest untuk menampilkan dan menganalisa sinyal getaran domain waktu dan domain frekuensi. Alat tes rig roda gigi dan instalasi pengujian ditampilkan pada Gambar 1.

Pada penelitian ini, sensor yang digunakan adalah akselerometer (tiga buah) dan sebuah tachometer optik yang berfungsi untuk merekam kecepatan putar poros. Sensor akselerometer ini dipasang pada 3 posisi yang berbeda, 2 sensor pada arah radial yang tegak lurus poros masukan dan 1 sensor pada arah aksial yang sejajar dengan poros masukan (Gambar 2). 


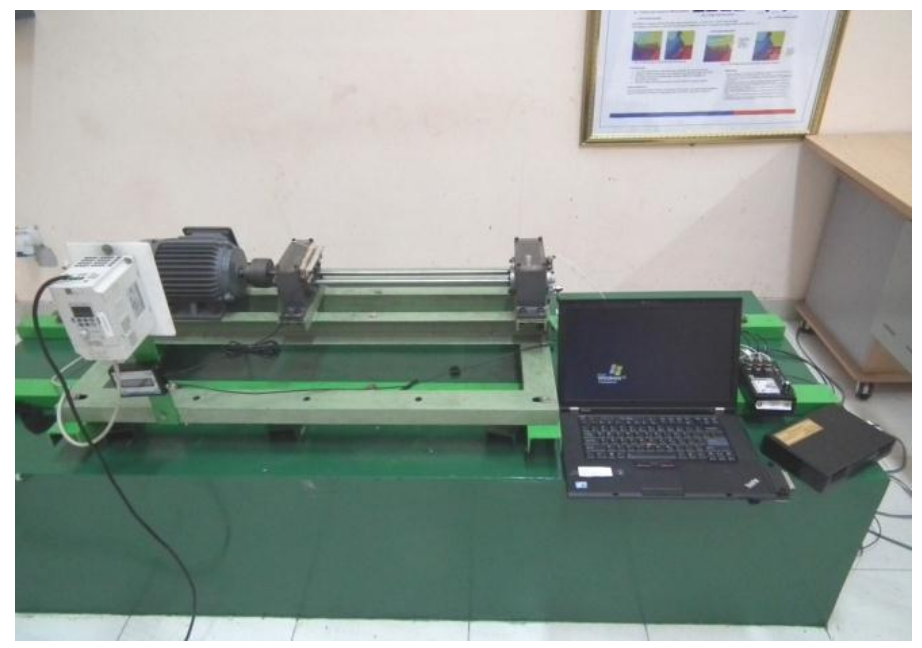

Gambar 1. Instalasi eksperimen pada tes rig roda gigi

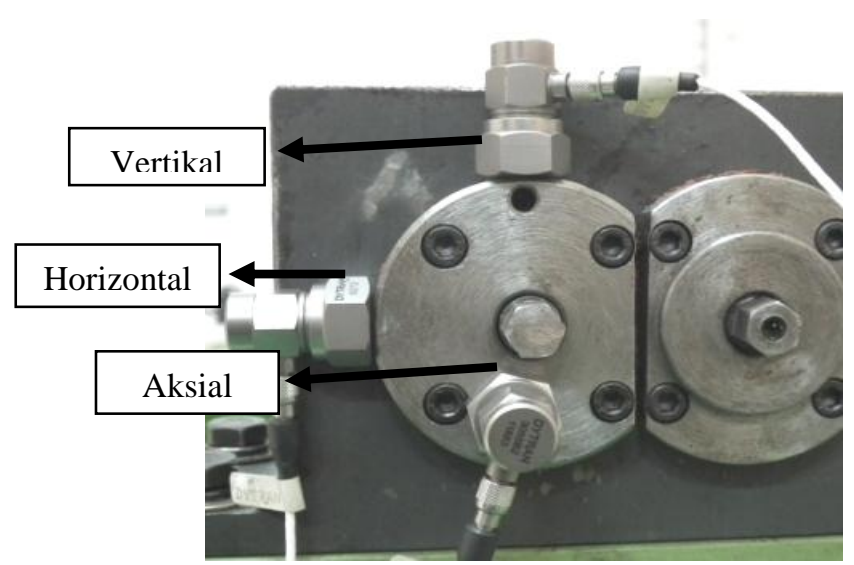

Gambar 2. Posisi sensor getaran pada perangkat uji

Data akuisisi sinyal getaran yang dilakukan pada roda gigi dengan variasi kondisi normal, aus, patah setengah gigi, dan patah satu gigi. Rasio kecepatan putar antara gear dengan pinion adalah 1:2. Gear mempunyai jumlah gigi sebanyak 30 gigi dan pinion dengan 15 gigi.

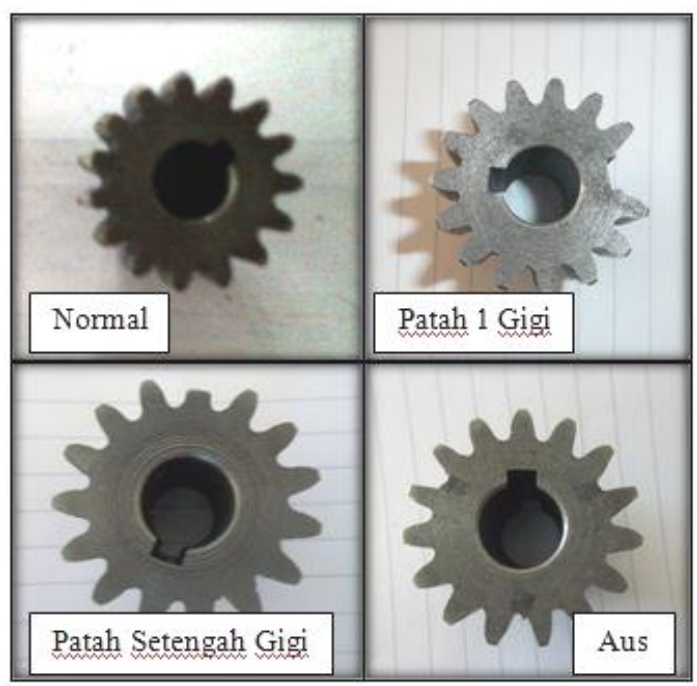

Gambar 3. Variasi kondisi kerusakan roda gigi

Roda gigi normal adalah benda uji pertama yang di uji, kemudian roda gigi aus, roda gigi patah setengah gigi dan terakhir patah satu gigi. Motor diputar dengan kecepatan $500 \mathrm{rpm}$ dan kemudian akan menghasilkan output sebesar $1000 \mathrm{rpm}$. Setiap benda uji diambil sampai 10 kali pengambilan data. 


\section{Hasil dan Pembahasan}

Data hasil pengujian selanjutnya diproses dengan menggunakan software bantu MATLAB. Pemrosesan data hasil pengujian dilakukan dengan tujuan untuk menganalisis sinyal getaran domain waktu dan domain frekuensi.

3.1 Domain Waktu

\subsubsection{Analisis TSA dan CWT}

Sinyal TSA akan menampilkan sinyal asli dengan cara mereduksi noise atau sumber getaran selain dari alat uji [2]. Sehingga kerusakan pada mesin dapat dideteksi dengan detil posisi kerusakan dan besarnya amplitude. Sedangkan prinsip analisis CWT adalah mengetahui fenomena besarnya amplitude sesuai dengan skalanya (dilatasi) $[3,4]$.

\subsubsection{Analisis TSA dan CWT pada kondisi normal}

Gambar 4 menunjukan getaran roda gigi pada kondisi normal memiliki amplitud tertingginya 0.24 Volt yang ditunjukan dengan grafik TSA dengan blok warna merah di putaran 206,3 ${ }^{\circ}$. Sedangkan untuk sinyal CWT yang diplotkan dari sinyal TSA dengan menggunakan skala warna dengan nilai gradasi warna 0.118 yang ditunjukan panah warna hijau.

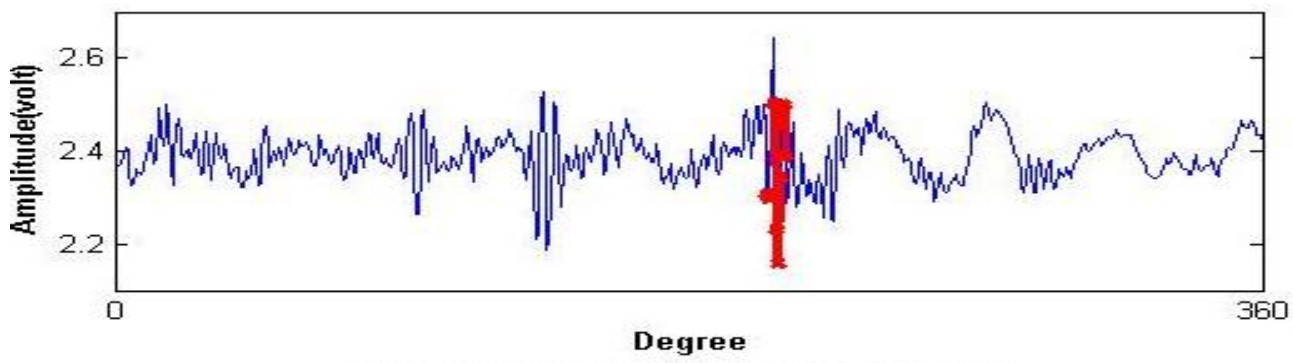

Continuous Transform, absolute coefficients.

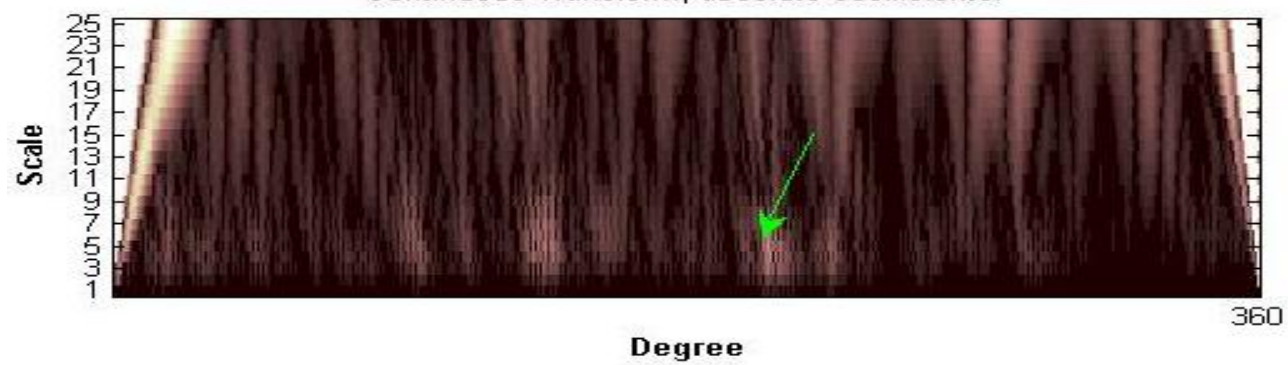

Gambar 4. Sinyal TSA dan CWT pada roda gigi kondisi normal

\subsubsection{Analisis TSA dan CWT pada kondisi aus}

Gambar 5 menunjukan getaran roda gigi pada kondisi aus memiliki amplitude tertingginya 0.30 volt yang ditunjukan grafik TSA dengan blok warna merah di putaran 112,2 ${ }^{\circ}$. Sedangkan untuk sinyal CWT yang diplotkan dari sinyal TSA dengan menggunakan skala warna dengan nilai gradasi warna 0.656 yang ditunjukan panah warna hijau.
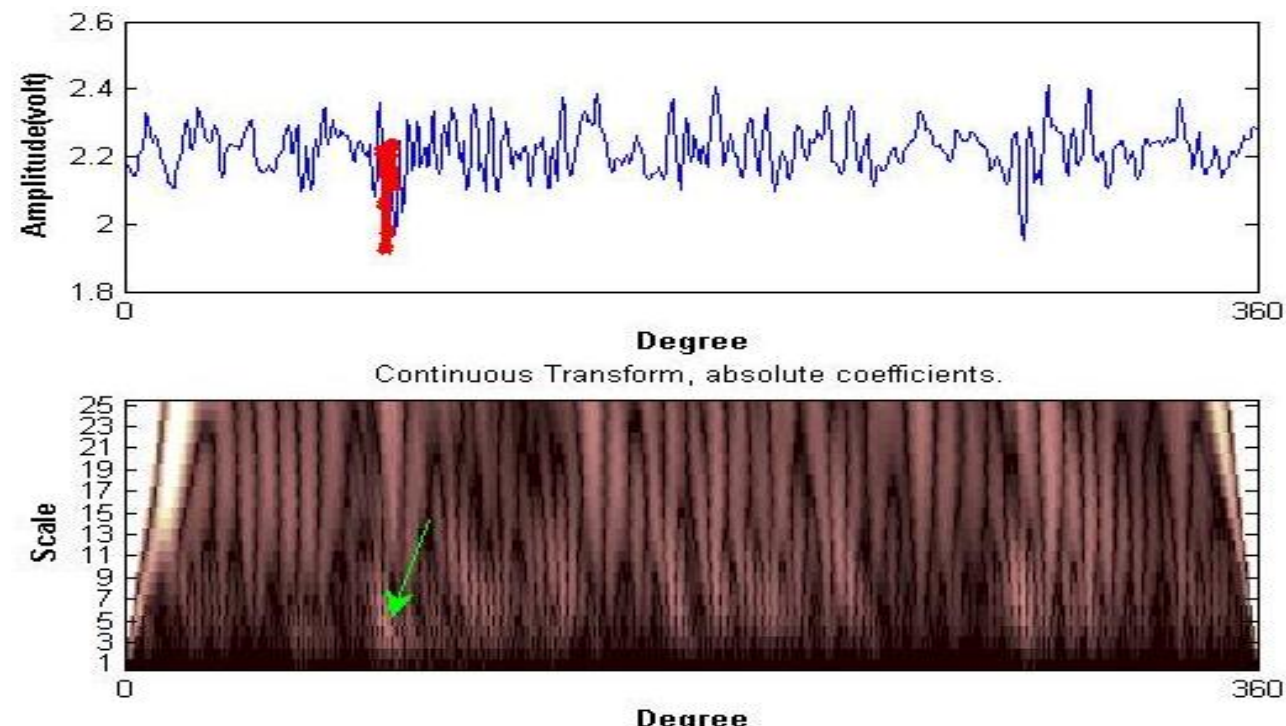

Gambar 5. Sinyal TSA dan CWT pada roda gigi kondisi aus 


\subsubsection{Analisis TSA dan CWT pada kondisi patah setengah gigi}

Gambar 6 menunjukan getaran roda gigi pada kondisi patah setengah gigi memiliki amplitudo tertingginya 0.25 volt yang ditunjukan grafik TSA dengan blok warna merah di putaran $321,4^{\circ}$. Sedangkan untuk sinyal CWT yang diplot dari sinyal TSA dengan menggunakan skala warna dengan nilai gradasi warna 0.401 yang ditunjukan panah warna hijau.

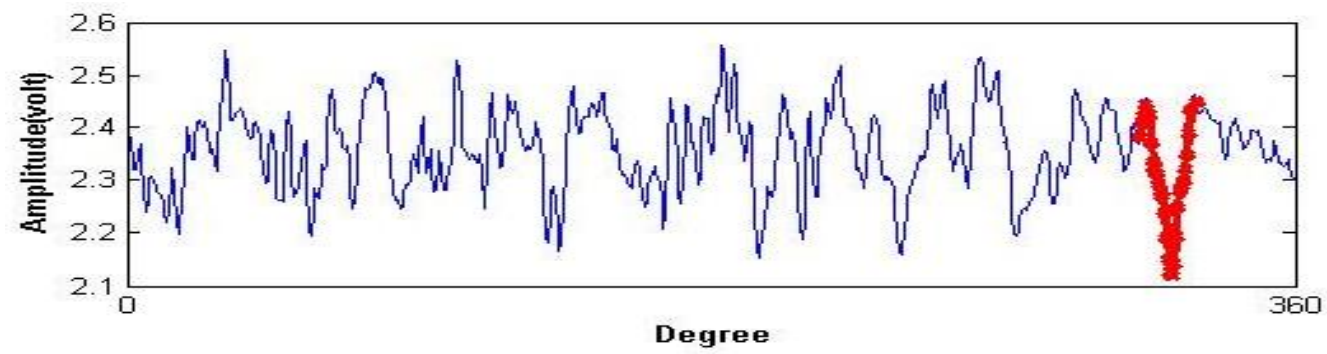

Continuous Transform, absolute coefficients.

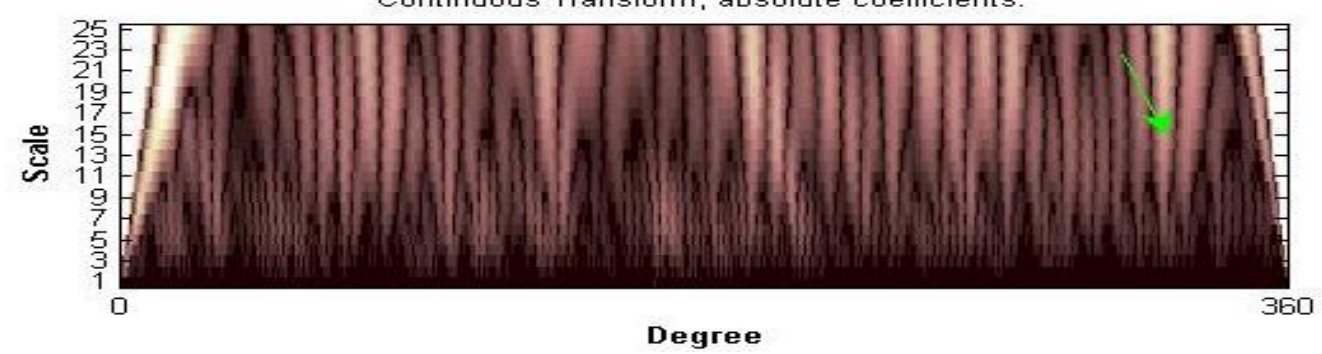

Gambar 6. Sinyal TSA dan CWT pada roda gigi kondisi patah setengah gigi

\subsubsection{Analisis TSA dan CWT pada kondisi patah satu gigi}

Gambar 7 menunjukan getaran roda gigi pada kondisi satu gigi memiliki amplitud tertingginya 0.35 volt yang ditunjukan grafik TSA dengan blok warna merah di putaran $325^{\circ}$. Sedangkan untuk sinyal CWT yang diplotkan dari sinyal TSA dengan menggunakan skala warna dengan nilai gradasi warna 0.773 yang ditunjukan panah warna hijau.
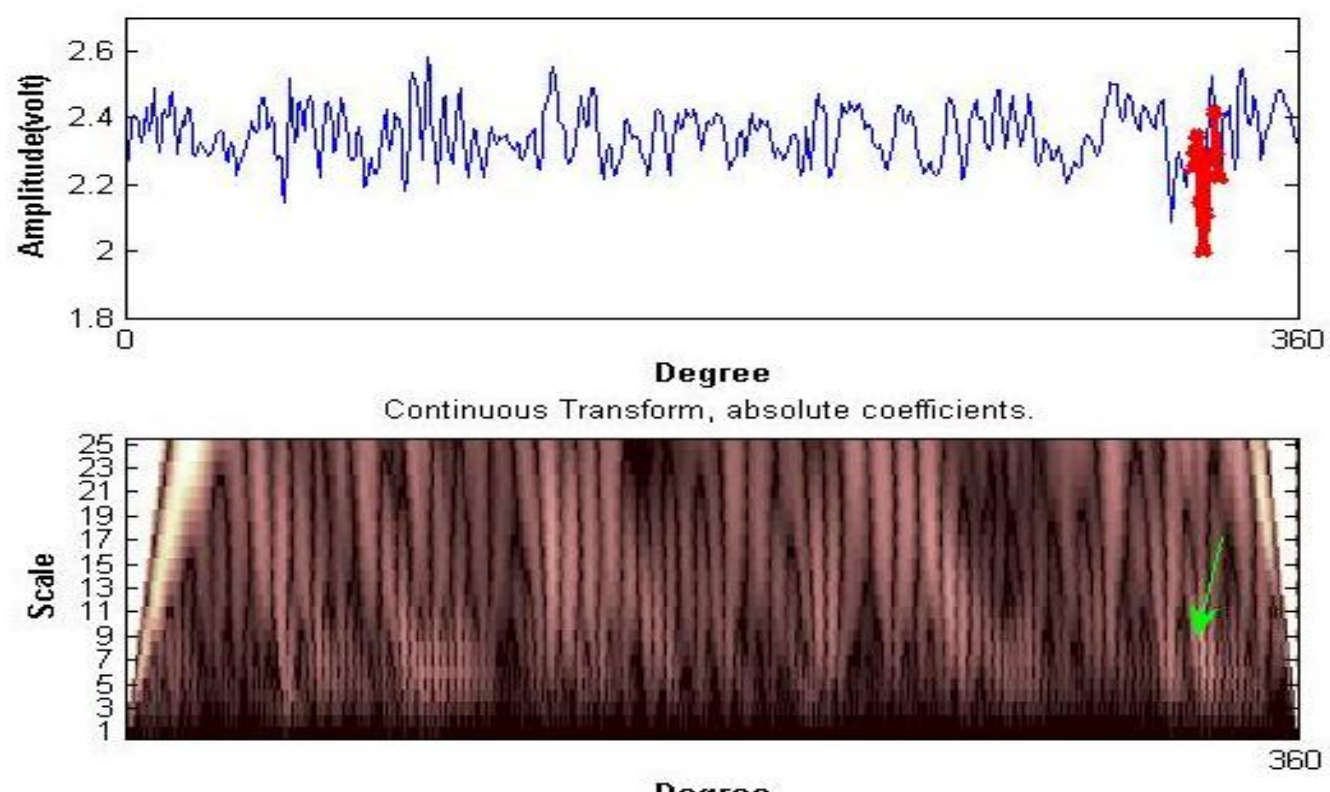

Degree

Gambar 7. Sinyal TSA dan CWT pada roda gigi kondisi patah satu gigi

\subsubsection{Analisis Sinyal Residual}

Gambar 8 menunjukan sinyal getaran dengan menggunakan residual signal. Pada gambar 8 tersebut terlihat bahwa untuk kondisi normal memiliki amplitudo 0.16 volt, kondisi aus memiliki amplitude sebesar 0,165 volt, kondisi patah setengah gigi memiliki amplitudo sebesar 0.175 volt dan kondisi patah satu gigi memiliki amplitudo sebesar 0,2231 volt. 

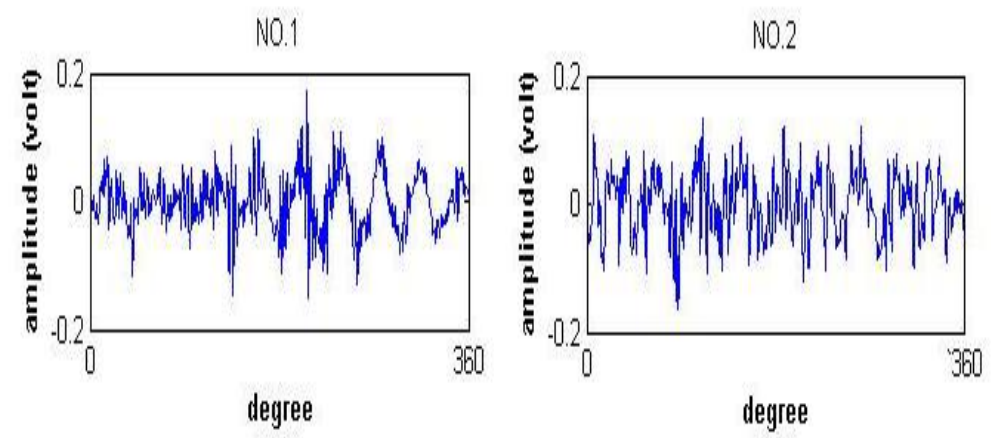

N0.3
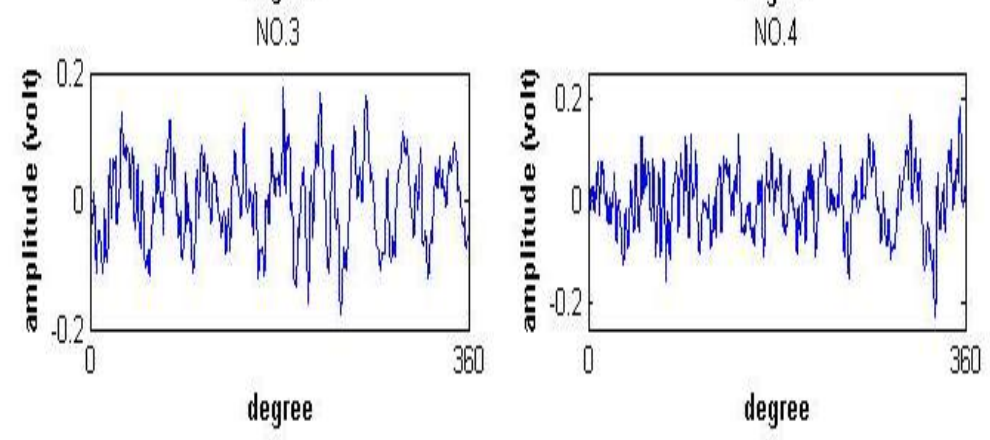

Gambar 8. Sinyal getaran residual pada roda gigi kondisi normal (1), aus (2), patah setngah gigi (3) dan patah satu gigi (4)

\subsection{Domain Frekuensi}

\subsubsection{Analisa FFT}

Sinyal getaran pada kondisi roda gigi normal spektrum getarannya menunjukkan 1 kali dan 2 kali RPM di sepanjang gear mesh frequency (GMF) [5,6]. GMF pada kondisi roda gigi normal terlihat berada pada frekuensi 253,5 $\mathrm{Hz}$ dengan amplitudo sebesar 0,0035 volt (Gambar 9). GMF tersebut pada umumnya akan memiliki side band yang relatif terhadap kecepatan poros gear.

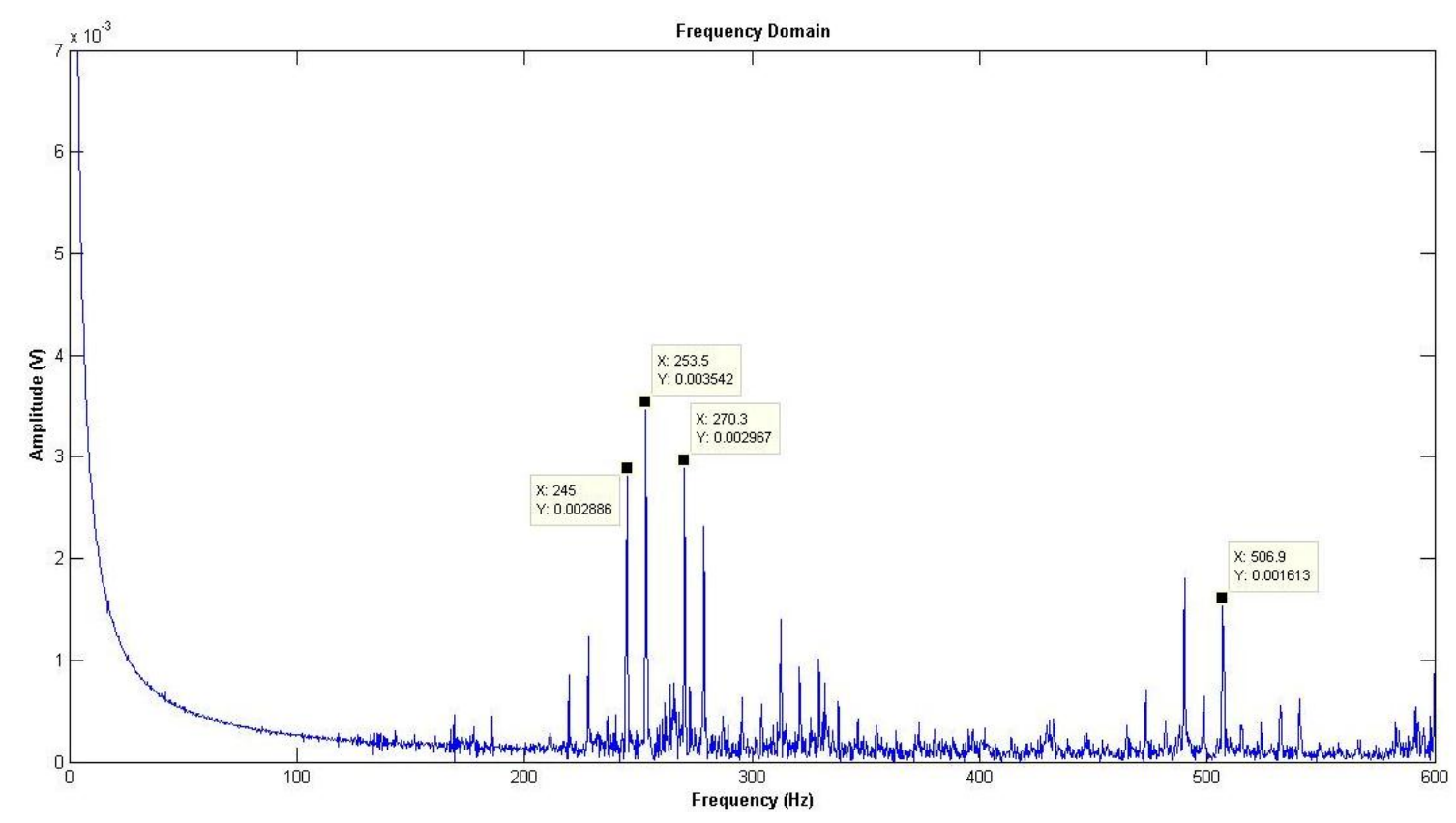

Gambar 9. Sinyal FFT pada kondisi normal

Pada kondisi roda gigi yang mengalami keausan memiliki spektrum getaran yang berbeda. Pada kondisi aus, GMF terlihat pada frekuensi $251 \mathrm{~Hz}$ dengan amplitudo sebesar 0,0036 volt (Gambar 10). Di sekitar GMF terlihat juga adanya frekuensi side band yang muncul dengan frekuensi yang tinggi. Amplitudo kontak gigi dapat mengalami 
perubahan ataupun tidak, tetapi munculnya side band dengan frekuensi yang tinggi di sekitar frekuensi kontak gigi biasanya terjadi ketika roda gigi mengalami keausan dan dapat menjadi indikator dari keausan pada roda gigi. Side band bisa menjadi indikator keausan yang baik daripada GMF itu sendiri.

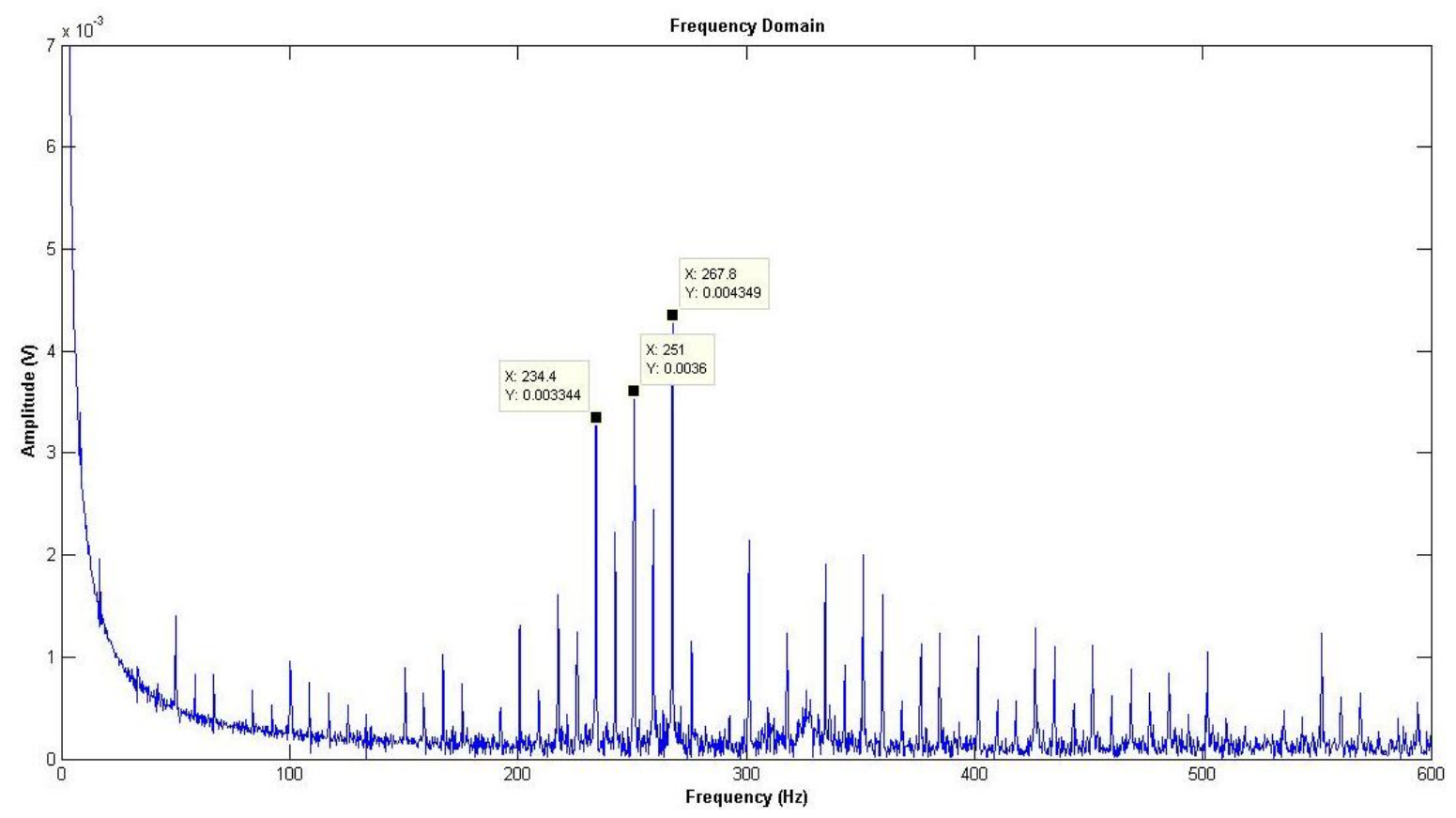

Gambar 10. Sinyal FFT pada kondisi aus

Pada kondisi roda gigi yang mengalami patah setengah gigi memiliki spektrum getaran yang hampir sama dengan kondisi aus dimana GMF dan frekuensi side band muncul dengan amplitudo yang tinggi. Pada kondisi patah setengah gigi, GMF terlihat pada frekuensi 252,5 Hz dengan amplitudo sebesar 0,0048 volt (Gambar 11).

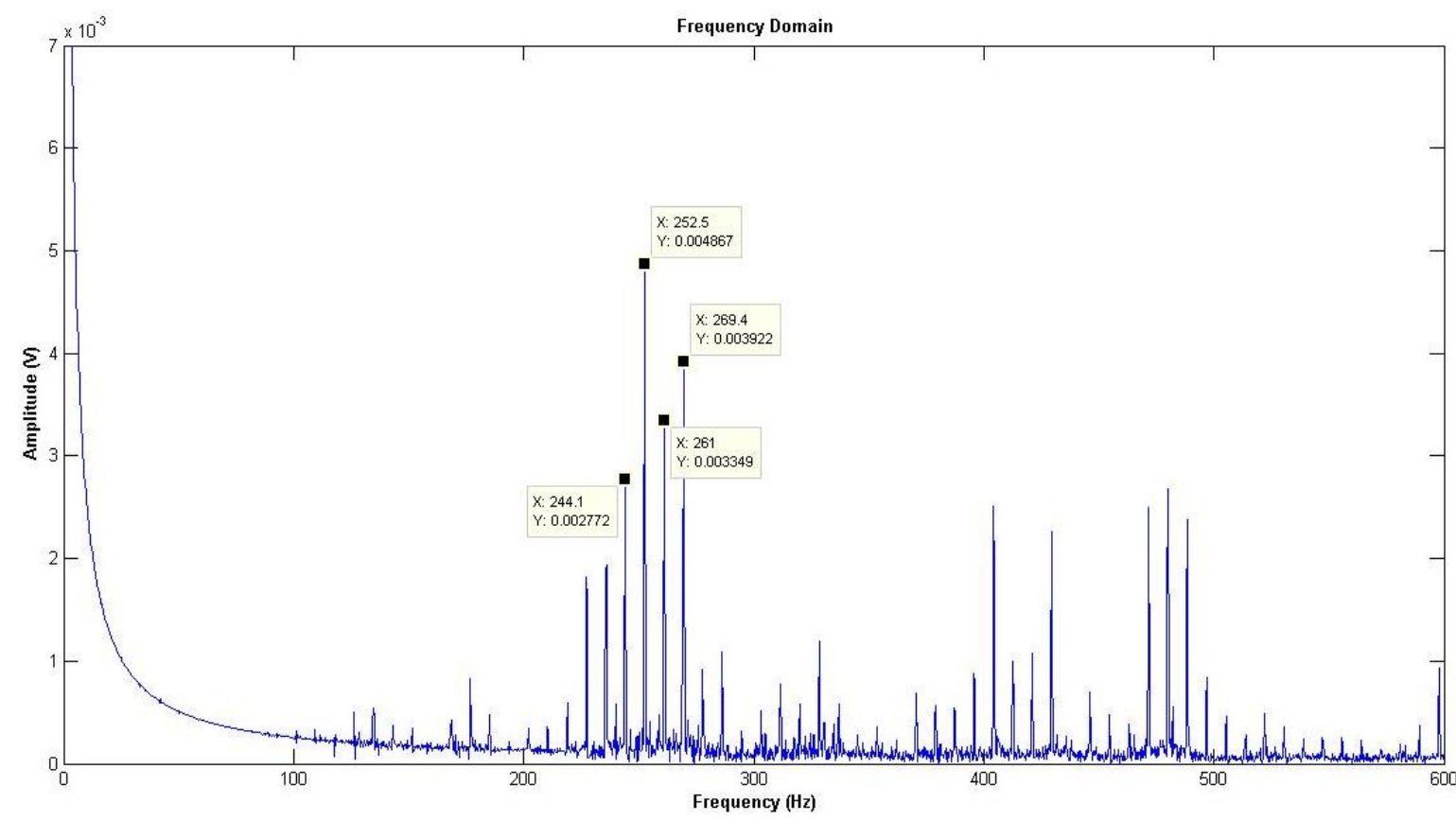

Gambar 11. Sinyal FFT pada kondisi patah setengah gigi

Pada kondisi roda gigi yang mengalami patah 1 gigi memiliki spektrum getaran yang hampir sama dengan kondisi patah setengah gigi. Tetapi pada kondisi patah 1 gigi, GMF terlihat pada frekuensi $235 \mathrm{~Hz}$ dengan amplitudo sebesar 0,0056 volt (Gambar 12). Terjadi perubahan GMF dari yang sebelumnya berada disekitar frekuensi $250 \mathrm{~Hz}$ 
menjadi disekitar frekuensi $133 \mathrm{~Hz}$. Hal ini terjadi karena adanya patah 1 gigi pada roda gigi tersebut. Perubahan nilai GMF ini dapat mengindikasikan bahwa terjadi crack pada roda gigi.

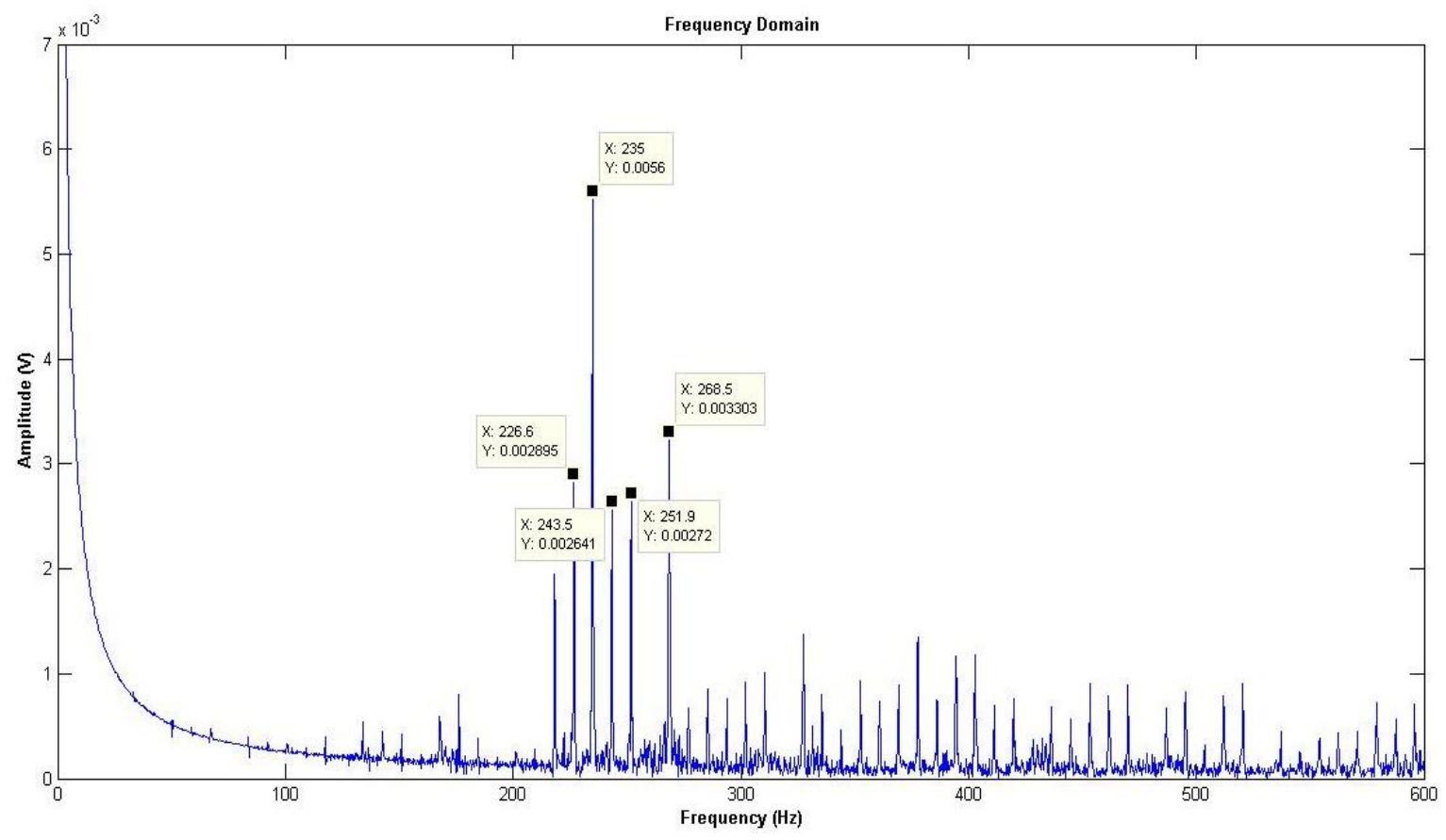

Gambar 12. Sinyal FFT pada kondisi patah satu gigi

\subsubsection{Analisa Cepstrum}

Pada pengolahan data sinyal cepstrum dari sinyal getaran, hasil yang ditamplikan berupa sinyal dari putaran poros [7]. Gambar 13 menunjukkan putaran poros beserta rahmoniknya pada kondisi roda gigi normal. Pada gambar ditunjukkan bahwa pada 1 kali putaran poros waktu yang ditempuh adalah 0,0591 detik dengan besar amplitudo 0,1142 volt. Tidak ada sinyal side band pada sinyal cepstrum kondisi roda gigi normal.

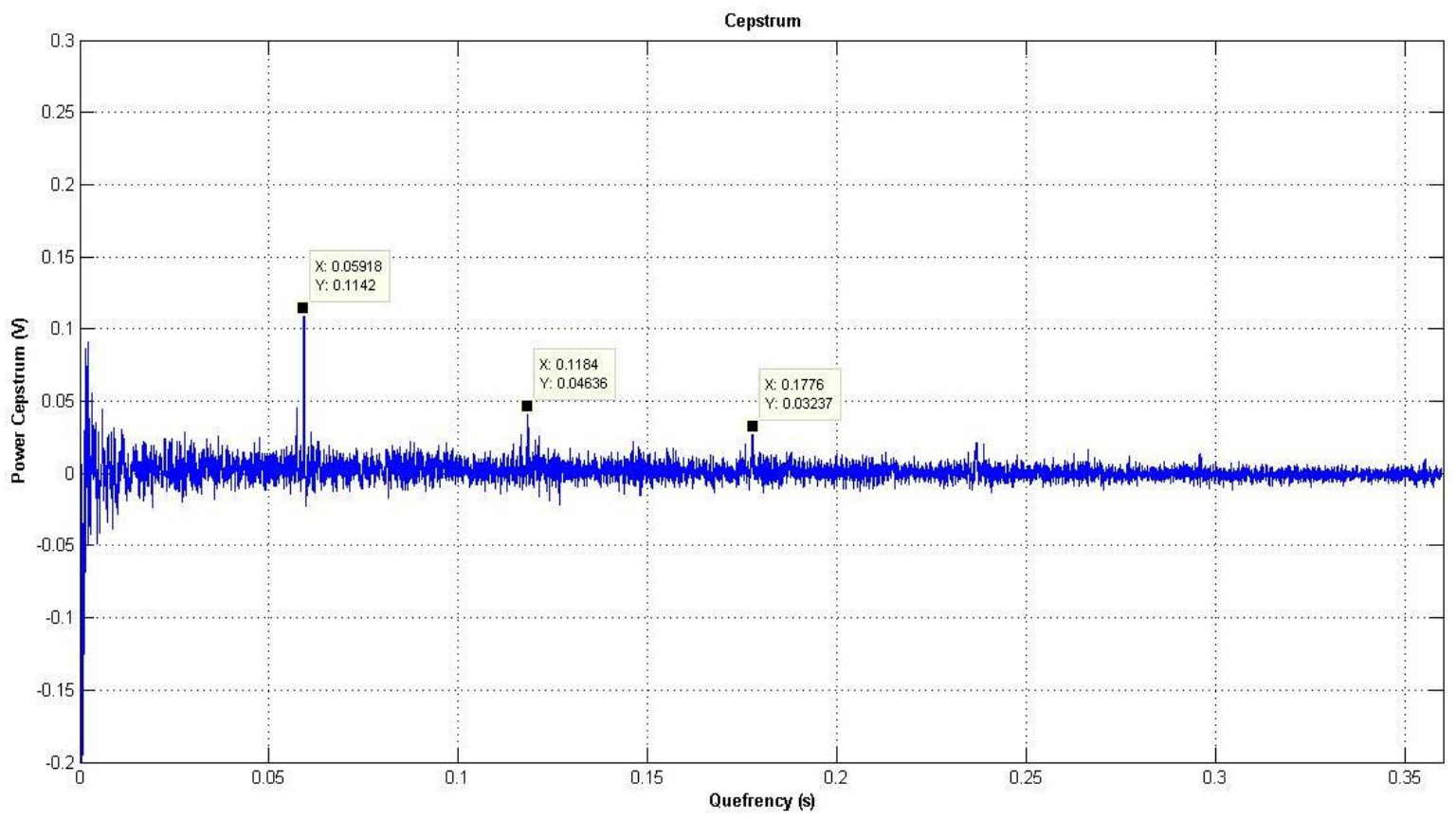

Gambar 13. Sinyal cepstrum pada kondisi normal

Putaran poros pada kondisi roda gigi aus beserta rahmoniknya ditunjukkan pada Gambar 14. Pada gambar ditunjukkan bahwa pada 1 kali putaran poros waktu yang ditempuh adalah 0,0597 detik dengan besar amplitudo 0,1839 
volt. Jika diperhatikan pada sinyal cepstrum kondisi roda gigi aus, terlihat adanya sinyal side band yang muncul. Sinyal side band beserta rahmoniknya muncul pada quefrency 0,0297 detik dengan amplitudo 0,4979 volt.

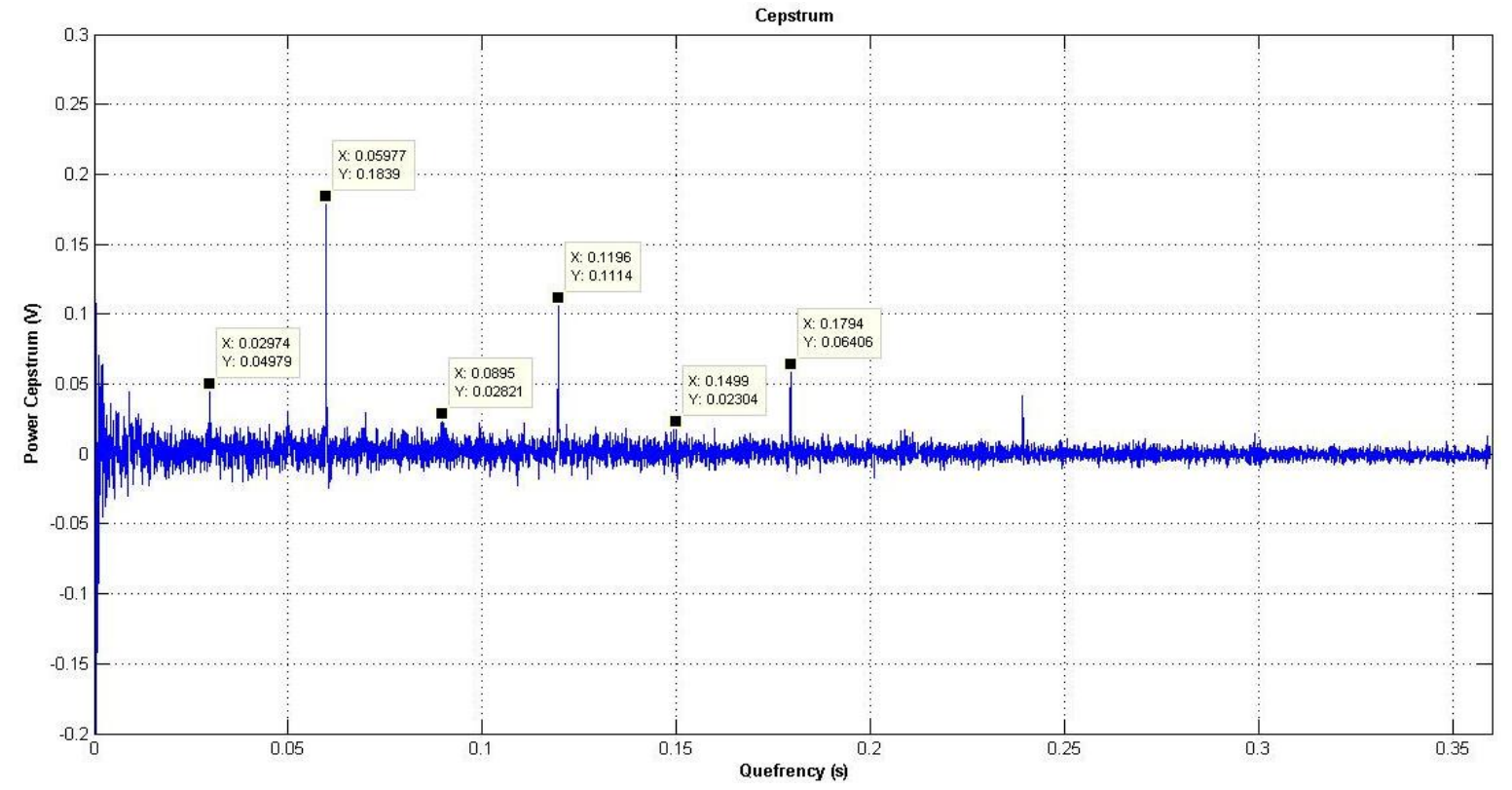

Gambar 14. Sinyal cepstrum pada kondisi aus

Putaran poros pada kondisi patah setengah gigi beserta rahmoniknya ditunjukkan pada Gambar 15. Pada gambar ditunjukkan bahwa pada 1 kali putaran poros waktu yang ditempuh adalah 0,0593 detik dengan besar amplitudo 0,2221 volt. Tidak ada sinyal side band yang muncul pada sinyal cepstrum kondisi patah setengah gigi. Tetapi jika dibandingkan dengan kondisi roda gigi normal, terlihat adanya perbedaan pada tinggi amplitudo dari sinyal cepstrum.

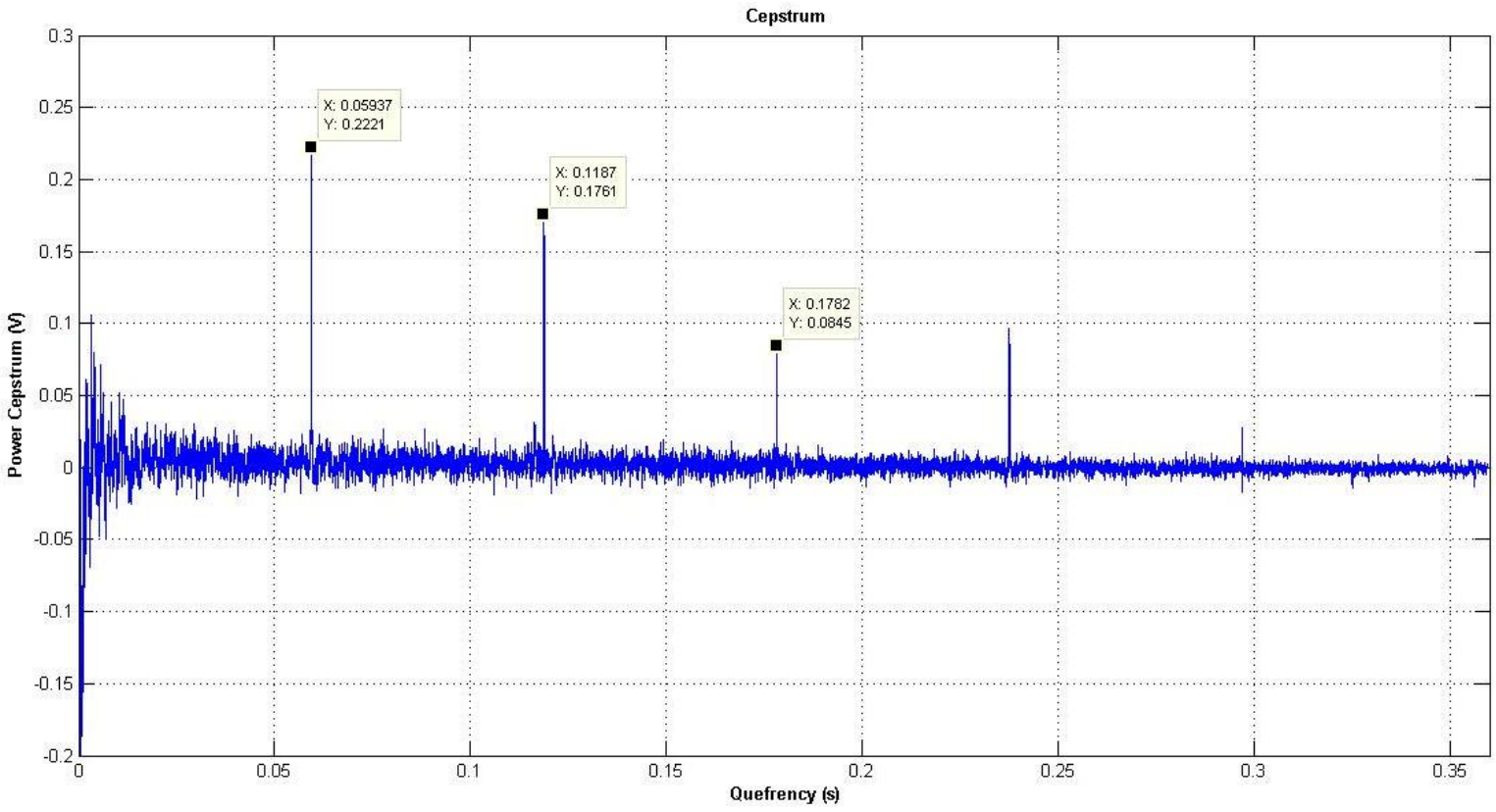

Gambar 15. Sinyal cepstrum pada kondisi patah setengah gigi

Putaran poros beserta rahmoniknya pada kondisi kerusakan patah satu gigi ditunjukkan pada Gambar 16. Pada gambar ditunjukkan bahwa pada 1 kali putaran poros waktu yang ditempuh adalah 0,0595 detik dengan besar amplitudo 0,2435 volt. Sama seperti pada kondisi patah setengah gigi, terlihat adanya perbedaan sangat tinggi pada amplitudo dari sinyal cepstrum yang mencapai 2 kali amplitudo pada kondisi roda gigi normal. 


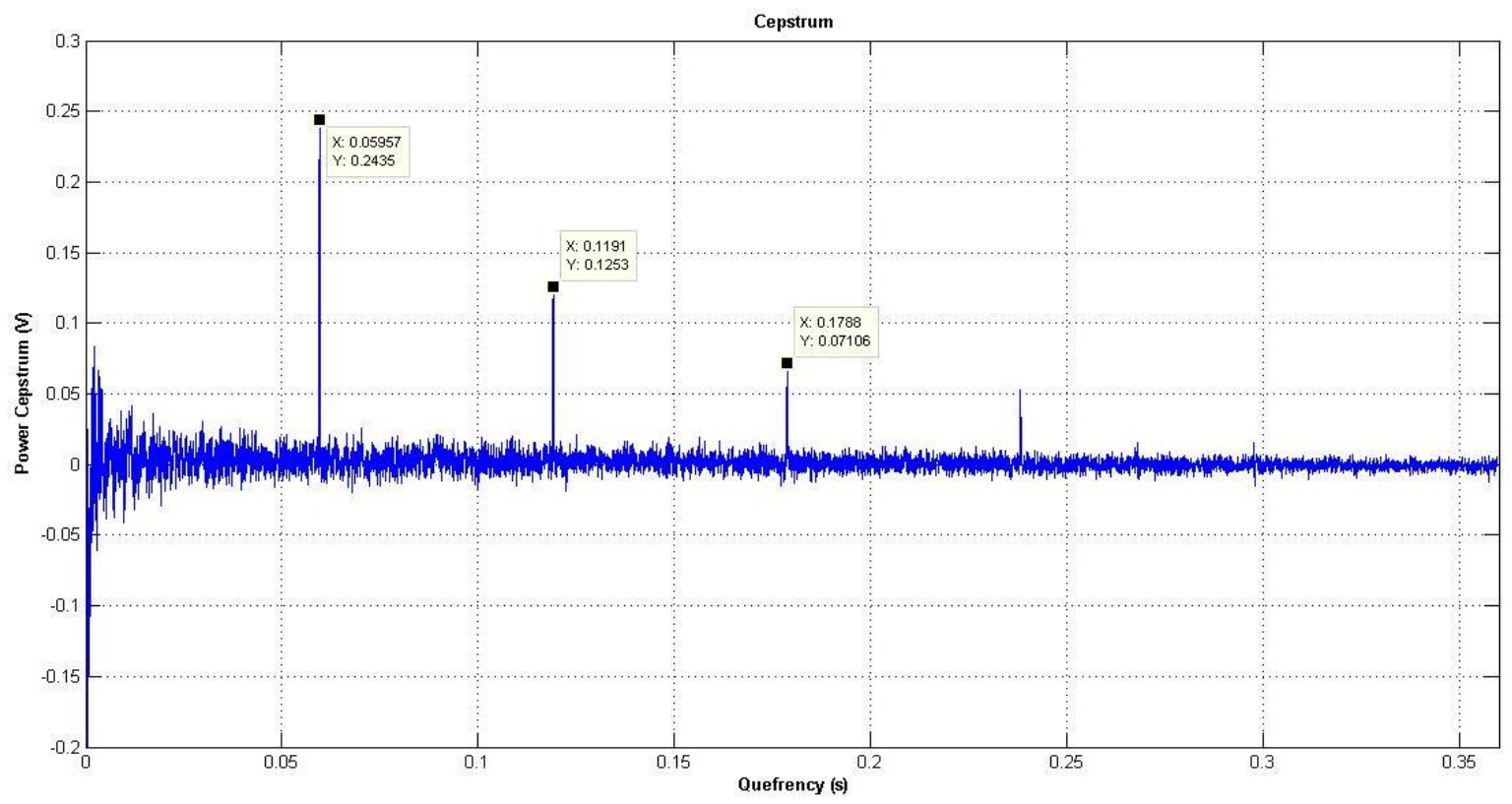

Gambar 16. Sinyal cepstrum pada kondisi patah satu gigi

Berdasarkan sinyal yang didapatkan dari hasil pengolahan, peningkatan amplitudo yang terjadi pada putaran awal rahmonik poros menunjukkan telah terjadinya kesalahan pada roda gigi. Indikasi dari terjadinya kerusakan pada sinyal cepstrum adalah terjadinya peningkatan amplitudo pada putaran awal dari rahmonik poros.

\section{Kesimpulan}

Karakteristik getaran yang ditunjukkan dengan melalui analisis TSA untuk roda gigi normal memiliki amplitudo yang lebih kecil dibandingkan dengan TSA sinyal getaran roda gigi aus dan patah.

Pada analissi CWT, degradasi warna hitam mendominasi kondisi normal dengan harga amplitudo relatif rendah, sedangkan untuk kondisi roda gigi aus dan patah mempunyai sebaran warna yang lebih terang (kecoklatan) yang menunjukkan besarnya harga amplitudo relatif yang lebih besar daripada kondisi normal.

Sinyal residual memiliki harga amplitudo lebih kecil dibanding sinyal TSA, hal ini dikarenakan sinyal residual dihasilkan dengan mengeliminasi GMF dan sideband.

Hasil pengolahan sinyal FFT menunjukkan perbedaan harga amplitudo FFT antara kondisi roda gigi normal dengan kondisi aus dan patah. Frekuensi daerah rusak dinyatakan dengan sidebands yang berada di sekitar GMF.

Hasil pengolahan sinyal cepstrum memperbaiki kualitas diagnosa dengan FFT. Dengan cepstrum nampak lebih jelas perbedaan tingginya amplitudo pada putaran awal poros antara roda gigi normal dengan roda gigi yang mengalami kerusakan.

Analisis hasil juga menunjukkan bahwa metode TSA dan wavelet mampu mendeteksi kerusakan roda gigi serta mampu menentukan lokasi relatif dari cacat roda gigi berdasarkan sudut putar. Metode cepstrum mampu mendetekasi frekuensi kerusakan roda gigi tetapi tidak bisa menentukan lokasi relatif cacat roda gigi berdasar sudut putar.

\section{Daftar Pustaka}

[1] Dalpiaz G., Rivola A. and Rubini R., Gear Fault Monitoring: Comparison Of Vibration Analisys Techniques. Mechanical System and Signal Processing, Vol.3, 387-412, 2000.

[2] P.D McFadden, A revised model for the extraction of periodic waveforms by time domain averaging, Mech. Sis. and Signal Proc. 1(1) (1987) 83-95.

[3] C.K. Chui, An introduction to wavelets, Academic Press, San Diego, 1992.

[4] P.D. McFadden, Application of the wavelet transform to early detection of gear failure by vibration analysis, Proceeding of an International Conference on Condition Monitoring, Swansea, UK, 1994, pp. 172-183.

[5] R.B. Randall, A new method of modelling gear faults, J. Mech. Design. 104 (1982) 259-267.

[6] R.B. Randall, Frequency Analysis, 3rd ed., Bruel\&Kjaer Publ., Naerum, Denmark, 1987.

[7] Tiwari, Ashesh. and Bhiwapurkar Himanshu. Fault Diagnosis of Gear box using Cepstrum Analysis. Devi Ahilya University, India, July 2013. 